\title{
Casa da noite: a morada da poesia de Hilda Hilst
}

\author{
Vitor Hugo Luís Geraldo* \\ Enivalda Nunes Freitas e Souza**
}

\section{Resumo}

Este artigo investiga a imagem da noite na poesia de Hilda Hilst, reverberando no fatigante encalço da escrita, na solidão amorosa, na indignação política, nas visões oníricas. Elemento ativo na Casa do Sol, lugar da oficina da palavra e do exercício da contemplação, a noite é valorizada por iluminar o inconsciente e liberar o espírito imaginativo, promovendo a linguagem fulgurosa da poesia. Para acompanhar esse tema, buscou-se o apoio de campos interdisciplinares, como a filosofia, a antropologia e a psicologia. Nesses campos, e na literatura, a compreensão moderna do tema noite é devedora da concepção noturna novalisiana.

Palavras-chave: Hilda Hilst. Noite. Novalis. Bachelard. Durand.

* Graduado em Direito pela Universidade Paulista. Graduando em Letras Francesas e Literatura Francesa pela Universidade Federal de Uberlândia (UFU). Membro do POEIMA - Grupo de Pesquisa Poéticas e Imaginário.

** Pós-Doutora em Estudos Literários pela UFMG. Doutora em Literatura Brasileira pela USP. Professora do Programa de Pós-Graduação em Estudos Literários da Universidade Federal de Uberlândia (UFU). Pesquisadora do POEIMA - Grupo de Pesquisa Poéticas e Imaginário. Autora de Flores de Perséfone - A poesia de Dora Ferreira da Silva e o sagrado (2013, Cânone/ FAPEMIG), além de organizadora de obras e autorias de artigos e capítulos de livros. Número orcid: https://orcid.org/00000001-6012-1224 


\section{House of the Night: the Hilda Hilst's Residence}

\section{Abstract}

This article investigates the image of the night in Hilda Hilst poetry, reverberating in the exhausting pursuit of writing, in loving solitude, in political indignation, in dreamlike visions. Active element in Casa do Sol, place of the workshop of the word and the exercise of contemplation, the night is valued for illuminating the unconscious and releasing the imaginative spirit, promoting the brilliant language of poetry. To move forward with this theme, support was sought from interdisciplinary fields, such as philosophy, anthropology and psychology. In these fields, and in literature, the modern understanding of the night theme is indebted to the Novalisian nocturnal conception.

Keywords: Hilda Hilst. Night. Novalis. Bachelard. Durand.

Recebido em: 29/08/2020 // Aceito em: 24/11/2020 
Amas a noite pelo poder de aniquilamento que encerra e sabes que, dormindo, os problemas te dispensam de morrer. Mas o terrível despertar prova a existência da Grande Máquina e te repõe, pequenino, em face de indecifráveis palmeiras. (ANDRADE, 1992, p.73)

\section{A cosmogonia da noite}

Triunfa na noite a profundidade e o zelo. O medo, a incognoscibilidade, a ignorância, e as faces e os corpos evanescendo à percepção, à noite se fundiram e se sedimentaram na imaginação do homem, onde nem a invenção edsoniana foi capaz de lançar luz e varrê-los do imaginário ocidental.

Os símbolos negativos atribuídos à noite se perpetuaram no tempo como o homem triunfou no mundo, "eldest of thing" escreveria Milton ao dizer que a noite era a mais velha das coisas ${ }^{1}$, uma vez que inúmeras simbologias dos povos ocidentais situaram-na em suas cosmogêneses como princípio gerador do mundo ou das forças primordiais nele coexistentes.

Tão caros à lógica da luz enquanto razão e conhecimento, esquecemo-nos da noite enquanto domadora dos homens e dos deuses, ${ }^{2}$ porque a ela se deve a primordialidade inaugural. Sua carga simbólica não sucumbiu às voragens de Cronos nem às esclarecidas revoluções do pensamento, mas se viu lançada à ebriedade do vinho, às idiossincrasias do romantismo onde poetas como Jean-Paul, Novalis, Byron e Azevedo, cantaram-na evidenciando no verso a plangente atmosfera melancólica e o isolamento que se abatia sobre o indivíduo.

Observando a imagem da noite pelo paradigma 


\section{Casa da noite: a morada da poesia de Hilda Hilst}

antropológico, constata-se que a imaginação humana de todas as culturas concebeu-a como um elemento originalmente misturado aos demais. Por obra divina, separou-se a noite do dia, reservando à luz uma dádiva aos homens, enquanto os malefícios se alojariam nas trevas. Com a luz, todos os medos seriam domados e o homem poderia enfrentar os perigos sem desvantagem.

Hesíodo, em sua Teogonia, atribuiu à noite (Nix) o status de deusa primordial, progenitora do Dia e de diversos outros deuses que se consubstanciam em abstrações e conceitos personificados:

$$
\begin{aligned}
& \text { Do Caos Érebos e Noite negra nasceram } \\
& \text { Da Noite aliás Éter e Dia Nasceram } \\
& \text { gerou-os fecundada unida a Érebos em amor. } \\
& \text { Noite pariu hediondo Lote, Sorte negra } \\
& \text { e Morte, pariu a grei de Sonhos. } \\
& \text { A seguir Escárnio e Miséria cheia de dor. } \\
& \text { (HESÍODO, 1995, p. 91). }
\end{aligned}
$$

O poeta grego atribui ainda, à noite, a descendência das Moiras, entidades que engendram e personificam o destino e a conduta dos homens e dos Deuses: "[...] que aos mortais tão logo nascidos dão os haveres de bem e de mal, / elas perseguem transgressões de homens e de Deuses [...]” (HESÍODO, 1995, p. 94), não havendo homem ou Deus cujo destino não tomassem parte, vez que ao observarmos a etimologia do nome, este advém de Moĩpal, correspondendo em grego à parte/repartidoras.

Nix é a noite que antecede o dia, a matriz da aurora, a benéfica para o pensamento e o espírito. Em contraposição à noite caótica, massa informe, Nix é a noite que gera o dia, uma noite positiva. Filha do caos (Kháos), adveio ao mundo juntamente com seus irmãos Terra (Gaia), Tártaro e Eros, compondo o panteão mais antigo e primordial da mitologia grega, povoando de deuses, 
seja em "fecundada" união ou partenogênese, o mundo por vir.

Pelas exíguas fronteiras que demarcavam as tradições grega e romana, Ovídio também cantou a ideia de primordialidade conferida à noite, concebendo a escuridão enquanto progenitora da luminosidade, do sol:

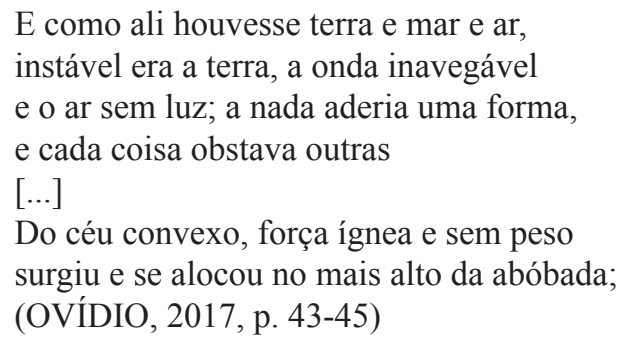

E como ali houvesse terra e mar e ar, instável era a terra, a onda inavegável e o ar sem luz; a nada aderia uma forma, e cada coisa obstava outras $[\ldots]$

Do céu convexo, força ígnea e sem peso surgiu e se alocou no mais alto da abóbada; (OVÍDIO, 2017, p. 43-45)

O poeta toma para si a empresa de cantar "das origens do mundo até os meus dias" (OVÍDIO, 2017, p.43), guiando-nos através do seu canto ao tempo das primordialidades - o mar, a terra, os céus - e tudo quanto se encontraria depositado na natureza. Este era um tempo de uma só face "à qual chamaram Caos" (OVÍDIO, 2017, p.43) em que tudo coexistia em coincidentia opositorum: "Nada mantinha a própria forma,/cada um se opunha aos outros porque, num único corpo/ o frio lutava com o quente, com o seco lutava o úmido,/ o mole lutava com o duro,/ o peso com o sem peso." (OVÍDIO, 2017, p. 43- 45).

A cosmogonia judaico-cristã aponta-nos a separação do dia e da noite como a primeira dádiva dos implementos criacionais:

No princípio criou Deus o céu e a terra. 2. E a terá era sem forma e vazia; e havia trevas sobre a face do abismo; e o espírito de Deus se movia sobre a face das águas. 3. E disse Deus: haja luz; e houve luz. 4. E viu Deus que era boa a luz; e fez Deus separação entre a luz e as trevas. Chamou Deus à luz Dia e às trevas, Noite [...] (BÍBLIA, 2009, p. 03.) 


\section{Casa da noite: a morada da poesia de Hilda Hilst}

Todavia, a cultura judaico-cristã não mais concebeu à noite sua primordialidade geradora, mas sim passou a revesti-la de conotações negativistas, incorporando malefícios, maldades, trevas, inaugurando e presentificando o dualismo maniqueu ao símbolo noturno e às imagens e figuras a ele pertencentes e adjacentes, tornando-o palco das imoralidades e dos desregramentos humanos, definindo a trajetória do homem em "termos de luz e de escuridão" (DELUMEAU, 1993, p. 96). Atribuiu-se à luz, portanto, um caráter moral e vivificante, e à noite - às trevas, à escuridão, e elementos semanticamente adjacentes - a pecha do desvirtuamento capaz de sentenciar o homem ao vale das sombras:

O cego [...] que não vê "a luz do dia", possui um antegosto da morte (Tobias, 3:17;11:8;5:11s). Quando termina o dia sobrevém os animais maléficos (Salmos 91:6), os homens que odeiam a luz - adúlteros, ladroes ou assassinos (Jó, 24: 13-17). Assim, é preciso implorar Àquele que criou a noite que proteja os homens contra os terrores noturnos (Salmos, 91:5). (DELUMEAU, 1993, p. 96).

Construiu-se ao redor dos símbolos, que semanticamente orbitam a noite, sensações negativas que apartariam o homem ocidental da razão, da ascensão espiritual, alcançada somente através da iluminação. Contudo, essa temerária noite, tão veementemente reiterada e repelida nas escrituras cristãs, possui o caráter fundante da essência de uma certa religiosidade, perfazendo-se como um caminho a ser percorrido, um labirinto no qual as paixões religiosas percorrerão os inextrincáveis corredores da alma sem qualquer fio que lhes albergue a trajetória. A noite é fonte de criação e libertação, mas esbarra em imagens perturbadoras que atravancam a realização dos projetos: 
[Noite] Nix simboliza o tempo das gestações, das germinações e das conspirações, que vão surgir à luz do dia em manifestações de vida. É muito rica em todas as potencialidades de existência, mas entrar na noite é regressar ao indeterminado, onde se misturam pesadelos, íncubos, súcubos e monstros. Símbolo do inconsciente, é no sono da noite que aquele se libera (BRANDÃO, 2007, p. 191, grifo nosso).

Essa noite que ora atravessa e ora é atravessada, na qual involuntariamente penetra-se sem a certeza da amabilidade do retorno, vislumbra-se não somente nas escrituras que registram a palavra e a vida do Cristo, mas na trajetória de muitos místicos da igreja: São João da Cruz singrou a profunda escuridão da alma; barqueiro de si, seu célebre poema, "Noite Escura", nos confidencia o percurso nos mistérios da noite, nos quais a alma do sujeito-lírico, em desmedida jornada, vogou no místico e desmedido silêncio que só se atribui à escuridão:

Na noite ditosa, em segredo, que ninguém me via, nem eu nada olhava, sem outra luz e guia senão a que no coração ardia.

Só esta me guiava Mais certa que a luz do meio-dia onde me esperava quem eu bem sabia, em lugar onde ninguém aparecia

Oh noite, que guiaste!

Oh noite, amável mais que a alvorada!

Oh noite que juntaste Amado com amada, Amada no Amado transformada!

(CRUZ, 1984, p. 71) 
Tomada enquanto guia, astrolábio referenciando os caminhos a serem percorridos, o poeta-místico traduz a escuridão enquanto venturosa presença, “[...] amável mais que a alvorada!"' (CRUZ, 1984, 71), adornando-a de adjetivos porque somente $a$ noite e na noite se consagrou a jornada mística necessária à transmutação capaz de unir "Amado com Amada", corporificando-os num só símbolo.

\section{"Eu preferia / A grande noite negra / A esta luz irracional da Vida": Hilst, Novalis e Nietzsche}

A bagagem simbólica pertencente à noite foi sorvida pelos pré-românticos e tragada pelos ultrarromânticos tal qual Cronos a devorar sua prole frente às profecias. Os valores do mistério noturno, o embaçamento da visão deturpando as formas existentes, a melancolia se evadindo dos espaços, a paisagem solar relegada às margens para cantarem-se os mistérios das profundezas do bosque, os sortilégios, as rupturas, o vinho aderindo aos estômagos e, por ventura, mitigando as tribulações humanas, "foram com efeito, os pré-românticos que exprimiram incansavelmente essa revalorização dos valores noturnos" (DURAND, 2001, p. 218).

A retomada destes valores se deveu à percepção do caráter fundante imanado das sombras, reinaugurando na linguagem o espírito enquanto potência de renomeação, já que o fenômeno noite se ligava intimamente às livres reverberações do inconsciente e do mistério, manifestamente representados na convergência do espírito com o mundo.

Em Novalis, a linguagem é colocada a serviço do espírito como potência de nomeação poética. O poeta além de ter 
contribuído valorosamente para o estudo da poesia concernente à teorização desta linguagem expressiva, responsabilizou-se, conforme observa Durand, na teorização "das imagens noturnas" (2001, p. 220):

[...] mais sagradas que as estrelas reluzentes são os olhos infinitos da Noite abertos sobre nós. Eles veem mais longe que os olhos pálidos das incontáveis legiões - prescindindo da luz eles sondam as entranhas da alma amante (...) tu me revelaste a Noite como fonte de vida, e de mim fizeste homem. Que a chama dos espíritos devore meu corpo e então, como aérea substância, eu possa em ti mais intimamente me dissolver e assim seja eterna a nossa noite de núpcias. (NOVALIS, 1987, p. 35)

Novalis restabelece no Romantismo a noite dos ventos amenos e iluminada por estrelas, retomando a essencialidade do símbolo cosmogônico grego; Nix é a noite que antecede o dia, a matriz da aurora, a benéfica para o pensamento e o espírito:

Há que sempre retornar a manhã? Nunca findará o poder terrestre? Fatal atividade consome o divino advento da Noite [...]A luz tem o termo de sua medida, mas o império da Noite está além do espaço e do tempo [...] eles não pressentem, das profundezas das lendas ancestrais, tu vens ao nosso encontro para revelar o céu e nos trazer a chave das mansões da beatitude, silencioso mensageiro de infinitos mistérios! (NOVALIS, 1987, p. 37)

A luz na escuridão provoca aquele meio tom mágico, convite à reflexão, que impulsionava Hilda Hilst às caminhadas noturnas. Luz e sombra nas árvores no pasto, no gado lento sob o sol escaldante, no espelho das águas, nas encostas das colinas, na grande figueira e seu banco acolhedor. Há, ainda, coqueiros altos circundando a Casa do Sol mal iluminada em seu interior, mas cujo pátio branco, no centro da construção, recebe abertamente a 
luz que atravessa os arcos e refrata no interior da casa.

Circundada pela sombra, a poeta engendra poemas que redimensionam a noite para além de seu aspecto tenebroso oponente ao dia, antes, a noite se mostra propícia à gestação da palavra que se recobre da percepção imaginativa, abrindo as portas do inconsciente ferido pela luz cegante da consciência, da razão que pressupõe o controle, colocando a poeta à espera do acontecimento da palavra, da fatigante busca e dos constantes recomeços: "Empoçada de instantes, cresce a noite / Descosendo as falas" (HILST, 2019 p. 450).

A noite da escrita se irmana à noite da solidão amorosa, porque se lua é convite, mais do que tudo é passagem de tempo, que se desenvolve em frustração e falta, "Três luas, Dionísio, não te vejo" (HILST, 2019 p. 259). Não tarda que o tempo resgate sua vocação cíclica e a noite se converta em superação: "Amor que se alimenta de uma chama / Movediça e lunada, mais luzente e alta" (HILST, 2019 p. 259).

A noite hilstiana está intimamente atrelada à noite romântica novalisiana, quando as matizes diurnas não mais detém a vivacidade do pensamento que reivindica cidadania, dignidade e verdades. Nix transpassa o homem despertando-o das dormências das profundezas da alma, descortinando sua visão "Cantando amor, os poetas na noite / Repensam a tarefa de pensar o mundo" (HILST, 2019 p. 286). As dinâmicas da estética diurna, a práxis apolínea, destituíram do homem a valorização do impulso dionisíaco.

Novalis legou à legião de poetas que o sucederam, a noite primigénia: aquela que impulsiona o homem à metamorfose, à criação e a revalorização dos aspectos do mundo, depondo Apolo - símbolo de luminosidade - do empíreo frontão da verdade e 
da racionalidade: "a noite torna-se para Novalis o que ela é para Eckhart ou S. João: o próprio reino da substância da intimidade do Ser.” (DURAND, 2001, p. 220).

Para o antropólogo, São João da Cruz ao eufemizar a noite eufemiza também a morte, promovendo a oscilação do símbolo noturno do polo negativo ao positivo (DURAND, 2001, p. 219). O estudioso francês vê no poeta místico o antecessor de Novalis e outros românticos que sagraram a noite como "jubilação dionisíaca" (DURAND, 2001, p. 219).

Para Nietzsche, Apolo, personificação solar grega, também era intimidade, cortina estética para a beleza, principium individuationis, mas a excessiva claridade ofende a visão, lançando-nos à criadora ilusão da eterna realidade diairética.

As imagens agradáveis e amistosas não são as únicas que o sujeito experimenta dentro de si com aquela onicompreensão, mas outrossim as sérias, sombrias, tristes, escuras, as súbitas inibições, as zombarias do acaso, as inquietas expectativas, em suma, toda a "divina comédia" da vida, com o seu Inferno, desfila à sua frente, não só como um jogo de sombras (NIETZSCHE, 2007, p. 29)

Em Novalis, a noite também é principium individuationis, todavia ela não só complementa o aspecto diurno como gera todas as metamorfoses do universo. Sua presença cobre a vida como um manto, e só ela é capaz de revelar "a magnificência prodigiosa do reino deste mundo":

Como monarca de terrestre Natureza, ela convoca cada força para metamorfose sem fim, ata e desata alianças sem conta, envolve com sua imagem celeste todo ser sobre a terra. - Sua presença, somente, revela a magnificência prodigiosa do reino deste mundo. (NOVALIS, 1987, p. 35) 
O símbolo apolíneo nunca fora deposto num gesto de abrupto rompimento, mas atenuado, vez que, embora representasse a aparência, não simbolizava a força metamórfica associada a Dionísio. Apolo primava pela individuação, pois aparência, enquanto Dionísio personificava as vias recônditas do ser:

[...] à ruptura do principium individuationis, ascende do fundo mais íntimo do homem, sim, da natureza, sernos-á dado lançar um olhar à essência do dionisíaco, que é trazido a nós, o mais de perto possível, pela analogia da embriaguez. (NIETZSCHE, 2007, p. 30)

Em Hilst percebe-se o relevo novalisiano e nietzscheano atribuído à noite, conjugado à transgressão da linguagem poética em que opera a imaginação criativa, emparelhando estas forças justapostas, fazendo com que esse claro-escuro excite a fantasia e transforme as mais "frias metáforas" em verdadeiras imagens:

\author{
Enterrei à noite minhas estrelas \\ Porque à noite as flores \\ Elaboram em silêncio \\ Suas cores.
}

Enterrei à noite minhas estrelas

Perdi graças e gigantes

Para não perdê-las.

Ah, mundo de terra e medo!

(HILST, 2019, p.102 )

Se a claridade apolínea trazia fadiga ao intento poético, é na noite que seu coração se abrasa, quando trama/inventa imagens libertadoras, revigorando os ânimos e a linguagem.

A noite é o devir, quando "enterrar" e "elaborar" são pares da ação de construir. Na lentidão noturna, tramam-se as nuances das palavras e da vida. As estrelas-palavras são entregues à paciência obstinada do trabalho da transfiguração. Mais do que 
um brilho, a palavra ganha, na solidão noturna, múltiplas cores, explosão de sentidos, uma chave para a vida eterna, superação do mundo de terra, que é a morte. A finitude da vida se expande na amplidão da noite por onde pervagam palavras-estrelas, porque é nela que se desfaz a urdidura da trama e as flores elaboram não somente suas cores, como seu perfume, mas todo caminhar noturno enseja perda e mudança.

\section{"A noite não consente a veleidade": a noite do si mesmo}

Em seu livro As estruturas antropológicas do imaginário, o antropólogo Gilbert Durand sistematiza a produção do pensamento humano em dois regimes, o noturno e o diurno. Contudo, é preciso ficar claro, a estrutura durandiana é figurativa: a hermenêutica das imagens e símbolos deve ser vista em constante deslizamento de possibilidades, nada é fixo.

São imagens simbólicas que o homem cria para exorcizar o medo da morte, ou seja, o peso da temporalidade. A imaginação é fruto das pulsões subjetivas e objetivas, e funciona como libertação, podendo ser averiguada em grandes constelações que tentam dar uma resposta ao tempo, funcionando como equilíbrio psíquico. No regime diurno, as imagens são dicotômicas e têm a função exata de separar e discernir, o que coloca a noite como ocasião tenebrosa e maléfica, uma ameaça que deve ser vencida. As faces do tempo se mostram terrificantes em elementos nictomórficos, por exemplo. A noite tenebrosa e a escuridão são assustadoras e presentificam o tempo devorador:

A imaginação das trevas nefastas opõe-se à imaginação da luz e do dia. Entre os primitivos, as trevas noturnas, a noite negra, constituem o primeiro símbolo do tempo. 
Para Bachelard, "uma só mancha negra, desde que sonhada nas suas profundezas, chega para nos pôr em situação de trevas" (DURAND, 2001, p. 91-92).

Se o regime diurno é marcado pela antítese, negação e separação, o regime noturno eufemiza e domestica as faces do tempo, mergulhando na intimidade das coisas: "Enquanto o pensamento solar nomeia, a melodia noturna contenta-se com o penetrar e dissolver." (DURAND, 2001, p. 224). A noite converte-se em manto estrelado de união, aconchego e intimidade, na medida em que é, também, o arauto do dia, a antemanhã, uma parte do movimento cíclico do tempo que espera reconciliar sua manifestação antagônica, domesticando suas imagens angustiantes e vencendo-o:

A noite não consente a veleidade

De retomar na memória e no tempo

O tempo em que eu senhora de vaidades,

Dissipava no verso o meu lamento.

Tempo não é, senhora, de inocências.

Nem de ternuras vãs, nem de cantigas.

Antes de desamor, de impermanência.

Tempo não é, senhora de alvoradas.

Nem de coisas afins, toques, clarins.

Antes, da baioneta nas muradas.

Tempo não é, senhora, de pastores.

Nem de roseiras, madrigais, violas.

Nem é tempo, vos digo, de ter pássaros

Azuis em vossas douradas gaiolas.

(HILST, 2019, p. 156 )

O tempo está aprisionado à noite porque não há espaço para a hesitação, tudo é descida e profundidade; não pode mais a memória persistir naretomada deum tempo anterior, "devaidades" 
onde a brevidade intumescia o verso; inocência e cantiga estão desfeitas na impermanência do eu, na transfiguração que a noite impõe ao sujeito, descarrilhando imagens telúricas e afetas à corporeidade, onde a música sucumbiu à prescindibilidade, e as cantigas, os clarins, madrigais e violas, não mais delas necessita Orfeu para reconfortar a descida e domesticar criaturas.

A hostilidade do tempo é palpável violência, "baioneta nas muradas", nada remete à hesitação telúrica, pastores, roseiras e pássaros não há, porque o tempo é de violenta voragem, e a noite desponta em reconfortante abrigo num tempo de escassas imagens aprazíveis. Só há o agora, e Nix reconforta a fuga no si-mesmo.

Durand observa a coexistência de dois regimes noturnos, chamando-os de Noturno místico e Noturno sintético, respectivamente: o que acolhe as antinomias e o que, tal como a roda e a árvore, é promessa de retorno e renascimento. O regime noturno é, então, a valorização da noite, "uma vez que este mundo noturno é a exata imagem invertida, como que num espelho, do nosso mundo" (DURAND, 2001, p. 218). Como o sujeito lírico que se desdobra e se constrói mediante pulsões subjetivas e coletivas, moldando sua linguagem para ser o espelhamento das manifestações da vida, as imagens, em atitude noturna, se redobram, desdobram, eufemizam.

Será no útero da noite que se dará o desfazimento da urdidura, da trama que representará a retomada de um tempo primordial, tempo onde a noite era símbolo fundante, "toda vida começa na escuridão, na fertilidade quente, úmida e frágil das coisas pequenas que se tornam grandes" (HOLIS, 2019, p. 86). Será no prisma da noite que o sujeito poético transpassará e acessará a noite simbólica e primordial de si mesmo, o tempo 
antes do eu, ressignificando o mito e as imagens que vivificarão no ato poético aqueles conteúdos inativos da psique. O noturno imporá ao eu a catábase e, consequentemente, sua projeção simbólica no/do mundo.

\section{"Vi as éguas da noite galopando entre as vinhas": uma noite assombrosa}

$\mathrm{O}$ artista, em seu processo criativo, está aberto à influência recíproca entre consciente e inconsciente, o que leva à criação de imagens simbólicas que tentam dar conta de emoções que se alojam, muitas vezes, nas profundezas do inconsciente. Os passeios noturnos de Hilda Hilst pelos arredores da Casa do Sol colheram sensações espantosas que the serviram de estímulo para a poesia. Mas, uma vez plasmada, a obra não exige o conhecimento de dados prévios para a sua compreensão, ainda que facilite seu entendimento. O processo criativo na perspectiva da psicologia das profundezas não é derivado exclusivamente de experiências biográficas, afirmou Jung ao perceber o reducionismo freudiano (JUNG, 1991). No entanto, a obra está entrelaçada com as vivências do artista, conscientes e inconscientes, projetando-se para fora dessas vivências.

$\mathrm{Vi}$ as éguas da noite galopando entre as vinhas

E buscando meus sonhos. Eram soberbas, altas.

Algumas tinham manchas azuladas

$\mathrm{E}$ o dorso reluzia igual à noite

$\mathrm{E}$ as manhãs morriam

Debaixo de suas patas encarnadas.

Vi-as sorvendo as uvas que pendiam

$\mathrm{E}$ os beiços eram negros e orvalhados.

Uníssonas, resfolegavam. 
$\mathrm{Vi}$ as éguas da noite entre os escombros

Da paisagem que fui. Vi sombras, elfos e ciladas.

Laços de pedra e palha entre as alfombras

E vasto, um poço engolindo meu nome e meu retrato.

Vi-as tumultuadas. Intensas.

E numa delas, insone, me vi.

(HILST, 2019, p.486)

O poema se desenvolve dentro de uma atmosfera onírica, quando o sujeito-lírico se identifica com uma noite em que a vigília serve apenas como revelação do estado finito da condição humana. Este sujeito se consome entre imagens de grande apelo vital - éguas, noite, uvas, orvalho, brilhos, sonho - e do inarredável destino que conduz à morte, manifesto nas patas encarnadas, nas sombras, elfos, ciladas e o poço convertido em abismo. Estas imagens que sugerem a finitude e a morte vêm à tona quando o sujeito-lírico, em vigília, é perpassado pela noite. As imagens do poema são elaboradas, desta forma, no jogo da vida e da morte, no permanente deslizamento entre o interno e o externo, bem como entre o inconsciente noturno e a razão que marca a vigília.

A simbologia animal, do reino teriomórfico, adensada pela feminilidade terrificante da égua, se associa às sombras noturnas, gerando uma imagem terrificante e assombrosa. Trevas e teriomorfia são imagens isomorfas (DURAND, 2001), juntas acentuam a angústia da finitude e do devir. Não há no inconsciente coletivo a imagem "éguas da noite", há "noite" enquanto manifestação do arquétipo de trevas e "éguas" como imagem da animalidade.

$\mathrm{Na}$ imagem que a poeta cria, esses elementos se juntam, "éguas da noite", numa forma visionária: "cada uma destas 


\section{Casa da noite: a morada da poesia de Hilda Hilst}

imagens contém um pouco de psicologia e destino humanos, um pouco de dor e prazer repetidos inúmeras vezes na nossa genealogia" (JUNG, 1991, p. 70). É assim que se explica a força imagística da poesia sobre o leitor: as imagens que o poeta cria não são reprimidas nem esquecidas por ele, são despertamentos artísticos de vivências mais profundas, comungadas por todos. Compreender a arte, assim, aparta a obra de seu criador.

"Éguas da noite" recupera as imagens cósmicas tão férteis na poesia hilstiana, mas cumprindo em sua novidade, ao longo do poema, o papel da imagem, que é revestir-se de carga psíquica o suficiente para exprimir um pouco que seja da interioridade humana:

O problema do poeta é, portanto, o de exprimir o real com o irreal. Vive [...] no claro-escuro de seu ser, sucessivamente trazendo ao real uma luz pálida ou uma penumbra - e cada vez dando à sua expressão uma nuance inesperada (BACHELARD, 1989, p. 82).

Um acontecimento, uma forma, podem despertar esses conteúdos psíquicos que o artista compartilha com todos os homens. Seu papel é encontrar a expressão adequada para esses extratos: "o símbolo é sempre um desafio à nossa reflexão e compreensão. Daí o fato de a obra simbólica nos sensibilizar mais, mexer mais com o nosso íntimo e raramente permitir que cheguemos a um deleite estético puro" (JUNG, 1991, p. 66), porque o símbolo é inesgotável em seu sentido, pelo seu tanto de mistério e ambiguidade. "Poesia é deixar ressoar através das palavras a palavra primordial" (JUNG, 1991, p. 68), que é uma imagem arquetípica, complementa Jung. A imagem arquetípica faz parte de nosso inconsciente coletivo, que não é outra coisa senão "possibilidades de ideias". 
Ao trazer imagens do mundo sombrio do inconsciente, o artista está plasmando a alma da humanidade, promovendo um equilíbrio no seu tempo histórico, compensando unilateralidades do pensamento consciente, e é isso que deve interessar à crítica literária (JUNG, 1991, p. 86). Portanto, se as éguas vislumbradas na palmeira são extensões de influxos imagéticos dos cavalos no pasto ou das telas de Eugène Delacroix, Giorgio De Chirico, Pablo Picasso, por exemplo, todas elas - o cavalo em sua gênese - enfrentam a racionalidade diurna, estética e existencial, e descortinam as riquezas do mundo assombroso que exorcizam temores quotidianos, fazendo da arte educadora do seu tempo.

\section{"A noite em verso torpe me atingia": um desdobramento do eu}

Nalguns dos mais proeminentes poemas da autora, a noite primitiva e geradora dos símbolos e da existência figurará a partir da identificação e confluência do eu com o mundo exterior: "Vem dos vales a voz. Do poço / Dos penhascos. / Vem funda e fria / Amolecida e terna, anêmonas que vi [...]" (HILST, 2019, p. 487):

Dunas e cabras, E minha alma voltada

Para o fosco profundo da Tua Cara.

Passeio meu caminho de pedra, leite e pelo.

Sou isto: um alguém-nada que te busca

Um casco. Um cheiro. Esvazia-me de perguntas.

De roteiro. Que eu apenas suba.

(HILST, 2004, p.486).

Será submersa na noite que estes conteúdos psíquicos, nomeados por Jung como inativos significados, se projetarão 
no mundo a partir da empática relação, e experienciação, com ele. Esta identificação e re-conhecimento com o mundo que lhe transpassa as carnes a as vivências, se expressará em imagens simbólicas mitologizadas, nas palavras de Collot: "O poeta projeta assim fora de si, na imagem das coisas e na ressonância do poema, a tonalidade afetiva de sua relação com o mundo, em que ele interioriza, em compensação, a matéria-emoção (...)" (2004, p.228).

A noite em verso torpe me atingia.

As coisas insofridas

Sofridas se faziam

Se eu repousasse a mão sobre suas vidas.

Umas tardes meus olhos repensaram

Uma alvura de águas pretendida.

Tão leve caminhei sobre essas águas

Que a memória foi quase imerecida.

Onde estavas então? Nem me sonhavas.

Deitei-me sobre um tempo que viria

E um ciclo de visões me revelava

Que no ódio dos deuses fui lembrada

Em alto voo de ave, a esquecida.

(HILST, 2019, p. 167)

A noite não traz apaziguamento ao sujeito lírico, mas atravessa-o com a potência de sua primiparidade, com a virtuosa força legada às forças primevas da natureza, ensejando no sujeito lírico a inversão pacífica das imagens existenciais. $\mathrm{O}$ mundo não mais se lhe afigura como anteriormente figurava, agora, trespassado pela noite, o íntimo das existências se põe diante dos olhos a fim de ressignificar as experiências antes inapreendidas, deslocando a memória à contemplação duma temporalidade apreendida somente pela imaginação, revelando e desvelando 
tanto o íntimo quanto a vontade, pois “[...] a melodia noturna contenta-se com o penetrar e dissolver." (DURAND, 2001, p. 224).

Esta colisão que se dá entre a noite e o sujeito lírico congrega à revelação imagética das "águas pretendidas”, cujo anseio não alçou à prática. Estas águas redobram o caráter gerador inerente ao símbolo noturno, característica essa própria do Regime Místico, ratificando a primordialidade do arquétipo atribuído à Nix enquanto mãe primordial:

“Essa água geográfica, que só é pensável em vastas extensões oceânicas, esta água quase orgânica à força de ser espessa, a meio caminho entre horror e o amor que inspira, é o próprio tipo da substância de uma imaginação noturna. Mas aí também o eufemismo deixa transparecer a feminilidade." (DURAND, 2001, p. 222, grifo nosso)

O torpor da noite engendra a memória a fim de evocar e depurar as imagens evocadas, as incita e as esquadrinha, desobedecendo a temporalidade, onde passado e futuro coabitam o mesmo encalço temporal: "deitei-me sobre um tempo que viria" (HILST, 2019, p. 167), cuja convergência incita a um duplo estado de contemplação, onde sujeito lírico e poesia rememoram-se na futuridade da visão do eu, reforçando o caráter personificante e gerador da noite, como está no Canto Sétimo de Sete Cantos do Poeta para o Anjo: "Alta noite/O que foi trevas em mim/em ti resplandecia”. 


\section{"Empoçada de instantes, cresce a noite / Descosendo as falas": o nascimento do poema}

Empoçada de instantes, cresce a noite

Descosendo as falas. Um poema entre-muros

Quer nascer, de carne jubilosa

E longo corpo escuro. Pergunto-me

Se a perfeição não seria o não dizer

E deixar aquietadas as palavras

Nos noturnos desvãos. Um poema pulsante

Ainda que imperfeito quer nascer.

Estando sobre a mesa o grande corpo

Envolto na sua bruma. Expiro amor e ar

Sobre as suas ventas. Nasce intensa

E luzente a minha cria

No azulecer da tinta e à luz do dia.

(HILST, 2019, p. 450)

A justaposição de imagens aflui rumo à dúvida. A noite é portentosa metamorfose, "Pergunto-me / Se a perfeição não seria o não dizer / E deixar aquietadas as palavras / Nos noturnos desvãos." (HILST, 2019, p. 450), mas não há palavras, símbolos e noturnos desvãos cuja noite não possa penetrar. Os símbolos já não mais encerram incoerência, agora materializam-se no poema, "ainda que imperfeito", pois, quem, senão a noite, para varrer os esconderijos do eu? Retoma ela dos símbolos a primordialidade da significância: as associações, as estruturas sintáticas, os enjambements e metáforas - abertos sobre a mesa, corpo-poema - personificam na estrutura e na linguagem o enigma do eu, não mais são o sujeito, são o poema ao qual o poeta, após laboriosa noite de trabalho, expira o sopro divino da criação: "Expiro amor e ar sobre as ventas". Nasce o poema ressignificando o sujeito, 
triunfa a noite na criação. Faz nascer um primeiro sentido jamais dito daquela forma a fim de reverberar na sensibilidade do leitor.

O triunfo da poesia é criar e entrançar palavras distintas fazendo nascer um primeiro sentido jamais dito daquela forma. "Empoçada de instantes, cresce a noite / Descosendo as falas" (HILST, 2019, p. 450). Neste verso percebe-se que ao adentrarse às profundezas das horas, a noite é inevitável desfazimento, crescendo nela a epifania dos homens, à qual a palavra encarnará na linguagem o símbolo primoroso advindo das galerias do inconsciente. Não à toa Penélope descosia o sudário no esplendor da noite: a fim de presentificar Odisseu, na memória da carne, o ardil noturno se fazia pertinência, porque irrompendo a manhã seus consortes não questionariam os mistérios decorridos da noite, pois metamorfose e modificabilidade.

Se na noite descosem-se as falas, os tecidos, os planos e as jubilações, também nela o sujeito encontrará oportuna ambiência ao aprofundamento nas intimidades do eu, vez que representa descida às primordialidades humanas "As histórias antigas estão repletas de descidas, a catábase para o mundo subterrâneo: Orfeu, Odisseu, Jesus. Eneias, Dante [...]" (HOLLIS, 2019, p. 85). Não por acaso o crescimento da noite vincula-se, diametralmente, ao ato de nascer intentado por um poema "entre-muros". A intimidade do poema que se vislumbra é a intimidade de si, dos desdobramentos do sujeito lírico ao ser transpassado:

Todos os acontecimentos mitologizados da natureza, tais como o verão e o inverno, as fases da lua, as estações chuvosas etc., não são de modo algum alegorias destas, experiências objetivas, mas sim, expressões simbólicas do drama interno e inconsciente da alma, que a consciência humana consegue apreender através de projeção - isto é, espelhadas nos fenômenos da natureza. (JUNG, 2012, p. 17-18) 


\section{Casa da noite: a morada da poesia de Hilda Hilst}

Os deslocamentos do eu, e as rupturas inerentes à metamorfose catabática encontram, constantemente, sobressaltos de dúvida, todavia crescem na carne, que é júbilo, e no corpo que já presentifica a escuridão. Para Durand essa conscientização corporal "é o grande sintoma da mudança do regime do imaginário" (2001, p. 202), lado a lado, "carne jubilosa" e "corpo escuro" deságuam num oxímoro, pois imagens justamente opostas albergadas nas estruturas do verso, vez que a carne é júbilo por que o corpo é trespassado de trevas, porém incorre-nos, quando da leitura, a associação de júbilo à chama de uma vela, a uma centelha orgástica, se corporificando graças à penetração noturna.

\section{Conclusão}

A celebração da noite envolta pela solidão, o cultivo da atmosfera noturna como propícia à criação (e ao desfazimento) do texto poético se faz presente na poética hilstiana apenas como mais um dos muitos desdobramentos do sujeito lírico. Símbolo de deslocamento impulsionador dos fluxos catabáticos, dos mecanismos de conhecimento e individuação, a noite todos os mistérios depuram e guarnecem pois, desde os tempos primitivos do homem, figurou como entidade primordial na cosmogênese dos povos ocidentais.

$\mathrm{O}$ influxo engendrado pela noite transpôs as fronteiras espaço-temporais, repercutindo, ainda hoje, nas sociedades e no imaginário do homem. Se houve um tempo onde a noite figurava como entidade capaz de deslocar o homem do seu status quo a fim de redimensioná-lo diante do mundo e de si mesmo, esse tempo ainda se faz presente, pois ainda hoje ela abre as 
comportas do imaginário, se notabilizando pelo poder gerador e transformador, poder este que triunfa na poesia, onde o ato criacional funde palavras distintas fazendo nascer um primeiro sentido jamais dito daquela forma.

Gaston Bachelard, notável leitor novalisiano, professa sua devoção à noite em uma de suas últimas obras, La flamme d une chandelle (publicado originalmente em 1961). A noite, com uma pequena luz sobre a mesa de trabalho, inflama a linguagem poética, opera a imaginação criativa, fazendo com que esse claroescuro excite a fantasia e transforme as mais "frias metáforas" em verdadeiras imagens: "a imagem, a verdadeira imagem, quando é vivida primeiro na imaginação, deixa o mundo real e passa para o mundo imaginado, imaginário" (BACHELARD, 1989, p. 10). A pequena luz traz familiaridade ao sonhante com seu inconsciente, de onde pode ativar as imagens mais ricas, acionando a visão íntima das coisas.

O claro-escuro não só é a imagem do psiquismo como também possui um valor estético, uma vez que impregna de fantasia as coisas que percebe. Nessa percepção, as imagens não significam outra coisa, são elas mesmas, são produtos de uma anima tranquila que extrai da linguagem formas e sentidos extraordinários. Na solidão de uma pequena luz, o poeta devaneia, rememora, elabora, desfaz, experimenta a melancolia, tranquiliza-se, resigna-se, tentando aprisionar os instantes perpétuos de dádiva amorosa, vendo as coisas como se fosse a primeira vez.

É nesse ambiente de claro-escuro que vinga a poesia da autora, brotando imagens da mais pura lucidez que reverberam os cambiantes tons noturnos, imagens que se elevam para as colinas e árvores e se rebaixam para os poços, as aguadas, as cisternas, 
grotas e labirintos do inconsciente. Na penumbra alastrada pelos raios solares, a palavra ardente e fogosa de poeta imagina formas atravessadas pelo sol e pela noite, caminhantes de uma mesma jornada, ocupantes de um mesmo espaço que desconhece o caos originário. A palavra harmoniza o que os sentidos acolhem.

\section{Referências:}

ANDRADE, Carlos Drummond de. Poesia e prosa. Rio de janeiro: Nova Aguilar, 1992.

BACHELARD, Gaston. A chama de uma vela. Rio de Janeiro: Bertrand Brasil, 1989.

BÍBLIA. Tradução de Almeida Revista e Atualizada. Barueri, São Paulo: Sociedade Bíblica do Brasil; Cultura Cristã, 2003.

BRANDÃO, Junito de Souza. Mitologia grega. Vol. I. Petrópolis: Vozes, 2007.

COLLOT, Michael. O sujeito lírico fora de si. Tradução de Alberto Pucheu. Revista Terceira margem. Rio de Janeiro, Ano VIII, n. 11, 2004, p. 175-177.

CRUZ, São João da. A poesia mística de San Juan de la Cruz. Tradução de Dora Ferreira da Silva. São Paulo: Cultrix, 1984.

DELUMEAU, J. História do medo no ocidente. São Paulo: Cia das Letras, 1993.

DURAND, Gilbert. As estruturas antropológicas do imaginário. São Paulo: Martins Fontes, 2001.

HESÍODO, Teogonia: a origem dos deuses. São Paulo: Iluminuras, 1995.

HILST, Hilda. Da Poesia. São Paulo: Companhia das Letras, 2019. 
HOLLIS, James. Mitologemas: encarnações do mundo visível. São Paulo: Paulus, 2005.

HOMERO, Ilíada. Tradução de Carlos Alberto Nunes. São Paulo: Edições Melhoramentos, s/d.

JUNG, Carl Gustav. O homem e seus símbolos. Rio de Janeiro. Ed. Nova Fronteira. 1991.

JUNG, Carl Gustav Os arquétipos e o inconsciente coletivo. Petrópolis: Vozes, 1991.

JUNG, Carl Gustav . Psicologia e poesia. In: O espírito na arte e na ciência. Tradução de Dora Ferreira da Silva, Ruben Siqueira Bianchi. Petrópolis: Vozes, 1991. p. 73-79

MILTON, John. Paraíso Perdido. São Paulo: Editora 34, 2016. NIETZSCHE, F. O nascimento da Tragédia. São Paulo: Escala, 2007.

NOVALIS. Hinos à noite. Mairiporã: Esfinge, 1987.

OVÍDIO. Metamorfoses. Edição bilíngue. Tradução, introdução e notas de Domingos Lucas Dias. São Paulo: Ed.34, 2017. 